\title{
UTILIZING COOPERATIVE INTEGRATED READING AND COMPOSITION (CIRC) WITH MOBILE LEARNING TO ENHANCE STUDENTS' READING COMPREHENSION.
}

\author{
Nirwanto Maruf ${ }^{1}$, Maya Rupa Anjely ${ }^{2}$ \\ ${ }^{1}$ Muhammadiyah University of Gresik. \\ nirwanto.maruf@umg.ac.id \\ ${ }^{2}$ Midwifery Academy of Tahirah Al Baeti Bulukumba. \\ mayaanjeli86@gmail.com
}

\begin{abstract}
This present study aims to find out the how significant the utilization of Cooperative Integrated Reading and Composition (CIRC) with mobile learning on students' reading comprehension. This study is conducted by using the quantitative method with preexperimental design. The instrument used in in this study was test sheet called as Reading Comprehension Test (RCT), and it employed in pre-test and post-test, it was developed and selected from student textbooks, story books, and authentic materials to measure students' reading comprehension achievement. The present results reveal that CIRC teaching strategy with mobile learning (m-learning) improved students' performance in reading comprehension, it was indicated from the result of paired samples test ( $t$-test) that the value of the t-observed significant is at .000 is lower than $.050(.000<.050$, this means students' improvement is significant after exposed by the experimentation (treatment) process. Based on the result, it concluded that the utilization of Cooperative Integrated Reading and Composition (CIRC) with mobile learning as teaching strategy can enhance students' reading comprehension.
\end{abstract}

Keywords: Cooperative Integrated Reading and Composition (CIRC), Mobile Learning, Reading Comprehension.

\section{INTRODUCTION}

Pedagogy is teaching and learning process that rely on various types of methods, therefore teachers are demanded to find ways to stimulate and encourage students in his/her teaching learning process (Gull \& Shehzad, 2015). Many teachers in Indonesia are still implementing traditional method of instruction, such as teachers act as they are the only one source of knowledge for students. Students have to listen to the teacher in the rest of the teaching hours. They do not have opportunity to discuss, share opinion and exchange ideas with other students, in the other words they do not interact each other. This situation unable students to understand the reading text well. Therefore, Cooperative Integrated Reading and

\section{British, Jurnal Bahasa dan Sastra Inggris}


Composition (CIRC) offers togetherness in working on a particular task by implementing instructional materials in group activities which stimulate students to develop their own and other's learning. CIRC demands students to work on team, interact to each other, distributes ideas and objective, and giving responses.

Theoretically, CIRC tends to enhance learner's reading comprehension productively. This kind of learning strategies gives appropriate occasion for learners to interact actively, evoke motivation and excitement between learners, and create enjoyment in learning (Hadiwinarto and Novianti, 2015). CIRC categories as a pedagogical strategy aims to encourage teamwork and interaction between learners so called cooperative learning (Johnson \& Johnson, 2017). Cooperative learning also created trust between learners and teacher, to practice learners to think productively, and to search for learning materials from other resources, to encourage learners to express their thoughts, to assist learners to appreciate each other, and most of all to learn cooperatively among other learners.

The evolution of information and communication technology are growing rapidly, and certainly give an impact to the pedagogical approaches. This evolution leads into a new and fastest of learning model so-called mobile learning (m-learning). This model of learning assigns learners and teachers to ingress pedagogic system by means of mobile link which can be accessed anytime and anywhere by applying mobile equipment. Koole (2010) argues that "m-learning is a process of interaction of mobile technologies, learning capacities, and social aspects of the learners". This situation alerts the educators that this learning model has offers current window of opportunity for the accessibility of new format of pedagogic approach. Due to those realities above, this research intends to utilize CIRC with mobile learning in order to enhance students' reading comprehension.

\section{RESEARCH METHOD}

This research is a pre-experimental design since it provided no control of extraneous variables in the form of one - group pretest- posttest design.

\section{British, Jurnal Bahasa dan Sastra Inggris}


Table 1. Pre-experimental Study Model

\begin{tabular}{cccc}
\hline GROUP & PRE - TEST & TREATMENT & POST - TEST \\
\hline Experimental & Reading & combination of & Reading \\
& Comprehension Test & CIRC with mobile & Comprehension \\
& (RCT) & Learning & Test \\
& & & $(\mathrm{RCT})$ \\
\hline
\end{tabular}

The participants of this research were second year students of SMPN. 1 Bantaeng, class 8A located at city of Bantaeng, Bantaeng regency, province of South Sulawesi. The total participants were 31 students. This research administered test sheets as instrument known as Reading Comprehension test (RCT). This RCT was employed in pre-test and post-test, and it developed and selected form student textbooks, story books, and authentic materials. It was used to measure students' reading comprehension of literary texts such as identifying main idea, understanding vocabularies, identify reference, and specific information.

The data of this research were obtained from results of the pre-test and posttest, then they were analyzed quantitatively employing statistical analysis of t-test in SPSS 16.0 program. While the validity and reliability of instrument, the researcher ensured that the instrument is valid and reliable by employing validity and reliability testing.

\section{RESEARCH FINDING AND DISCUSSION}

\section{Finding}

\section{Students' performance in pre-test and post-test.}

Table 1. Students' Score distribution on pre-test and post-test.

\begin{tabular}{ccccccc}
\hline \multicolumn{3}{c}{ RESULT OF PRE-TEST } & \multicolumn{3}{c}{ RESULT OF POST-TEST } \\
\hline NO & NAME & SCORE & CLASSIF & SCORE & $\begin{array}{c}\text { CLASSIF } \\
\text { ICATION }\end{array}$ & ACHIEVEMENT \\
& INITIAL) & & ICATION & & Good & Improve \\
\hline 1 & A.BTFA & 63 & Fair & 75 & Poor & Improve but same Classification. \\
\hline $\mathbf{2}$ & ARA & 43 & Poor & 54 & Good & Improve \\
\hline $\mathbf{3}$ & AKD & 65 & $\begin{array}{c}\text { Fairly } \\
\text { Good }\end{array}$ & 75 & & Fairly \\
& AJPS & 60 & Fair & 74 & Good & Improve \\
\hline $\mathbf{4}$ & AAA & 45 & Poor & 64 & Fair & Improve \\
\hline
\end{tabular}




\begin{tabular}{|c|c|c|c|c|c|c|}
\hline 6 & ARP.NAS. & 66 & $\begin{array}{l}\text { Fairly } \\
\text { Good }\end{array}$ & 72 & Good & Improve \\
\hline 7 & AMA & 46 & Poor & 75 & Good & Improve \\
\hline 8 & AAF & 66 & $\begin{array}{l}\text { Fairly } \\
\text { Good }\end{array}$ & 77 & Good & Improve \\
\hline 9 & AR & 34 & Very Poor & 54 & Poor & Improve \\
\hline 10 & DK & 24 & Very Poor & 34 & Very Poor & Improve but in same classification \\
\hline 11 & INM & 36 & Poor & 57 & Fair & Improve \\
\hline 12 & JS & 38 & Poor & 54 & Poor & Improve but in same classification \\
\hline 13 & KVA & 39 & Poor & 61 & Fair & Improve \\
\hline 14 & MBR & 24 & Very Poor & 33 & Very Poor & Improve but in same classification \\
\hline 15 & MF & 32 & Very Poor & 41 & Poor & Improve \\
\hline 16 & MM & 35 & Poor & 53 & Poor & Improve but in same classification \\
\hline 17 & MTU & 63 & Fair & 75 & Good & Improve \\
\hline 18 & MTY & 40 & Poor & 59 & Fair & Improve \\
\hline 19 & NAZ & 60 & Fair & 68 & $\begin{array}{l}\text { Fairly } \\
\text { Good }\end{array}$ & Improve \\
\hline 20 & NAR & 41 & Poor & 67 & $\begin{array}{l}\text { Fairly } \\
\text { Good }\end{array}$ & Improve \\
\hline 21 & NAR & 71 & $\begin{array}{l}\text { Fairly } \\
\text { Good }\end{array}$ & 78 & Good & Improve \\
\hline 22 & NRR & 64 & Fair & 69 & $\begin{array}{l}\text { Fairly } \\
\text { Good }\end{array}$ & Improve \\
\hline 23 & $\mathrm{RM}$ & 35 & Poor & 48 & Poor & Improve but in same classification \\
\hline 24 & RWM & 65 & $\begin{array}{l}\text { Fairly } \\
\text { Good }\end{array}$ & 78 & Good & Improve \\
\hline 25 & SAF & 72 & $\begin{array}{l}\text { Fairly } \\
\text { Good }\end{array}$ & 81 & Good & Improve \\
\hline 26 & SH & 55 & Fair & 72 & $\begin{array}{l}\text { Fairly } \\
\text { Good }\end{array}$ & Improve \\
\hline 27 & SLA & 39 & Poor & 54 & Poor & Improve but in same classification \\
\hline 28 & $\mathrm{~S}$ & 57 & Fair & 68 & $\begin{array}{l}\text { Fairly } \\
\text { Good }\end{array}$ & Improve \\
\hline 29 & SF & 64 & Fair & 75 & Good & Improve \\
\hline 30 & SS & 44 & Poor & 53 & Poor & Improve but in same classification \\
\hline 31 & WSA & 67 & $\begin{array}{l}\text { Fairly } \\
\text { Good }\end{array}$ & 76 & Good & Improve \\
\hline & Sum & 1553 & & 1974 & & \\
\hline
\end{tabular}

Table 2. The rate percentage of achievement

\begin{tabular}{ccccc}
\hline & & & \multicolumn{2}{c}{ ACHIEVEMENT } \\
\cline { 4 - 5 } NO & CLASSIFICATION & SCORE & F & \% \\
\hline 1 & EXCELLENT & 95 to 100 & 0 & 0 \\
\hline 2 & VERY GOOD & 85 to 94 & 0 & 0 \\
\hline 3 & GOOD & 75 to 84 & 11 & 35.48 \\
\hline 4 & FAIRLY GOOD & 65 to 74 & 6 & 19.35 \\
\hline 5 & FAIR & 55 to 64 & 4 & 12.90 \\
\hline
\end{tabular}

\section{British, Jurnal Bahasa dan Sastra Inggris}




\begin{tabular}{rcccc}
\hline 6 & POOR & 35 to 54 & 8 & 25.81 \\
\hline 7 & VERY POOR & 00 to 34 & 2 & 6.45 \\
\hline IN TOTAL & & $\mathbf{3 1}$ & $\mathbf{1 0 0 . 0 0}$ \\
\hline
\end{tabular}

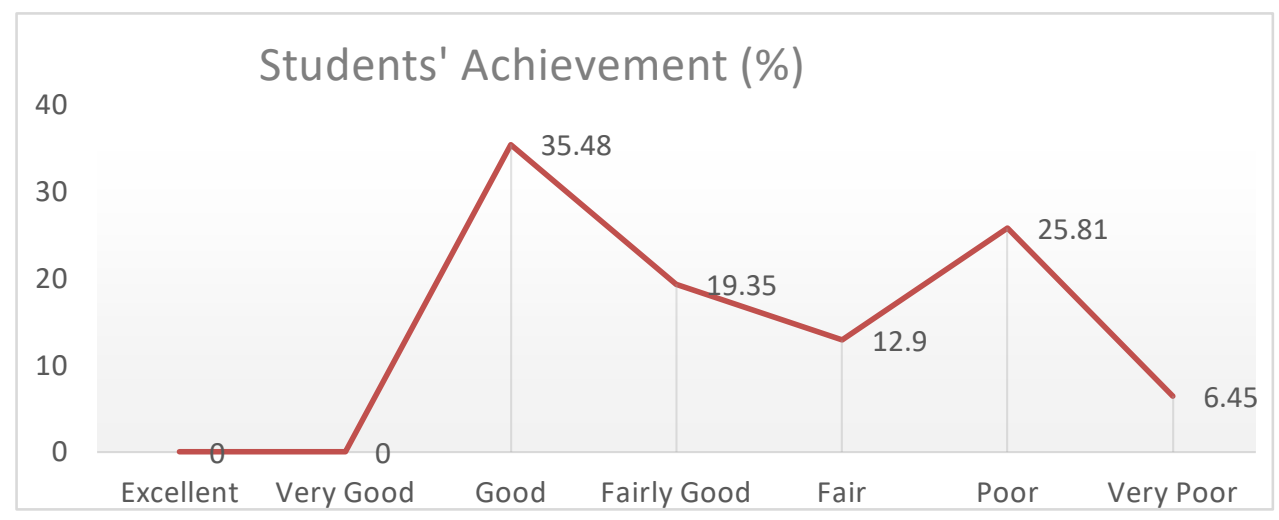

Graph 1. Chart of students' achievement

\section{The mean score and paired t-test of students' performance}

Table 3. The Mean and std. deviation of students' performance

\begin{tabular}{|c|c|c|c|c|c|}
\hline \multicolumn{6}{|c|}{ Paired Samples Statistics } \\
\hline & & Mean & $\mathrm{N}$ & Std. Deviation & Std. Error Mean \\
\hline \multirow[t]{2}{*}{ Pair 1} & SCORE_PRE & 50.10 & 31 & 14.664 & 2.634 \\
\hline & SCORE_POST & 63.68 & 31 & 13.242 & 2.378 \\
\hline
\end{tabular}

Table 4. The Paired samples correlations

\begin{tabular}{|l|r|r|r|}
\hline \multicolumn{1}{|c|}{ Paired Samples Correlations } \\
\begin{tabular}{|ll|r|r|r|}
\hline & \multicolumn{1}{c|}{$\mathrm{N}$} & \multicolumn{1}{c|}{ Correlation } & \multicolumn{1}{c|}{ Sig. } \\
\hline Pair 1 SCORE_PRE \& SCORE_POST & 31 & .917 & .000 \\
\hline
\end{tabular}
\end{tabular}

Table 6. Result of paired sample statitstic

Paired Samples Test

\begin{tabular}{|c|c|c|c|c|c|c|c|}
\hline \multicolumn{5}{|c|}{ Paired Differences } & \multirow[b]{3}{*}{$\mathrm{T}$} & \multirow[b]{3}{*}{ Df } & \multirow{3}{*}{$\begin{array}{l}\text { Sig. (2- } \\
\text { tailed) }\end{array}$} \\
\hline \multirow[b]{2}{*}{ Mean } & \multirow{2}{*}{$\begin{array}{c}\text { Std. } \\
\text { Deviation }\end{array}$} & \multirow{2}{*}{$\begin{array}{c}\text { Std. Error } \\
\text { Mean }\end{array}$} & \multicolumn{2}{|c|}{$\begin{array}{c}95 \% \text { Confidence } \\
\text { Interval of the } \\
\text { Difference }\end{array}$} & & & \\
\hline & & & Lower & Upper & & & \\
\hline
\end{tabular}

British, Jurnal Bahasa dan Sastra Inggris 


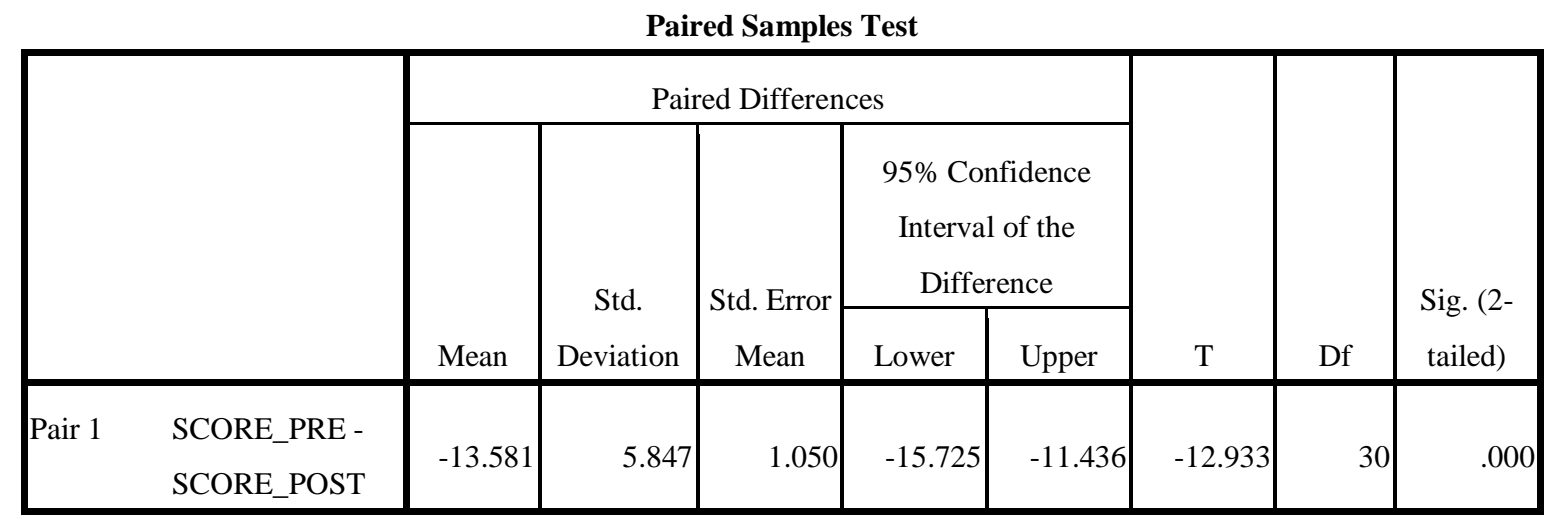

Base on the data above, there are $6.45 \%$ (2) students classified in very poor level, and $25.81 \%$ (8) students classified in poor level. But the data also indicates that there are $35.48 \%$ (11) students classified in good level, $19.35 \%$ (6) students classified in fairly good level and $12.90 \%$ (4) students in fair level (see graph. 1).

The data of students' achievement after post-test indicates that the improvement occur in students' performances. The improvement can be noticed from the divergence of mean score of pre-test and post-test (see table 4). The mean score has improved from 50.10 to 63.68 , so there is improvement in 13.58 point, and in standard deviation of pre-test is 14 . 664 whereas the post-test is 13.242. Since the post-test is higher than pre-test (pre-test < post-test), thus it can be summed up that there are improvement in learning results among pre-test and post-test.

The correlation test outcomes (see table 5) shows that correlation coefficient values is 0.917 with the significant value is 0.000 , and since the significant value is lower than 0.05 , it can be determined that there is a relationship among the pretest and post-test variables with a strong and positive correlation level of 0.917 (closer to 1).

The difference is claimed to be significant if the observed significance is lower than $5 \%$ at the level of significant. By thoroughly examine the outcomes of paired samples test (t-test) reveals that the t- observed significance is lower than 5\%. The value of the $\mathrm{t}$ - observed significant is at .000 which is lower than $.050(.000<$ .050) (see table 6). This means the students' improvement is significant after employed the experimentation (treatment) process.

\section{British, Jurnal Bahasa dan Sastra Inggris}




\section{Discussion}

Cooperative Integrated Reading and Composition (CIRC) is one of the variant of Cooperative learning (CL) (Mubarok \& Sofiana, 2017) developed by Robert Slavin. This kind of cooperative learning offers togetherness in working on particular task by implementing instructional materials in group activities which develop students learning (Johnson and Johnson, 1995). Cooperative learning demands learners to work on team and interact with others, distributes ideas and giving responses.

As mentioned earlier that the objective of this research was to utilize the Cooperative Integrated Reading and Composition (CIRC) with mobile learning on learners' reading comprehension achievement. The result of this research reveals the effect CIRC as the teaching strategy on students' reading ability is significant. This result is in compliance with research establish by Zarei and Keshavarz (2011) which indicates that the utilization of CIRC in order to improve students' reading comprehension is proven effective. Meanwhile, Gupta and Ahuja (2014) have concluded that the cooperative learning provides learners to have a chance to work together to achieve mutual goals, and increase students' motivation in reading.

In CIRC, learners are assembled in a small groups, this assists learners to complete the task given promptly and in short time. Also, learners are feel more enjoyable in competing the task since they have a chance to share their ideas in the way the liked. This contention in line with Atkins (2010) statement that learners could learn more desirable with each other and the teacher is no more as the only one source of information in class. In this research, learners were requested to work together to obtain information from the text easily and cooperatively. Moreover, the utilizing of CIRC as the pedagogical strategy in improving students' reading comprehension. The finding reveals that the participant of research or students gains better achievement in reading after they were engaged with CIRC teaching strategy with mobile learning. 


\section{CONCLUSION AND SUGGESTION}

The elaborated results can be concluded that CIRC teaching strategy improves students' reading performance. The form of CIRC strategy offers learners empirical, relevant and applicable as well as practical activities to enhance learners' performance in reading. In a group, learners could work and collaborate each other to achieve mutual goals by discussed the material provide. Furthermore, the researcher concludes that the utilization of Cooperative Integrated Reading and Composition (CIRC) with mobile learning can be able to enhance students' reading comprehension achievement. Therefore, based on the finding o f this study, researcher recommends this CIRC pedagogical strategy with mobile learning to any English teachers to implement this teaching strategy in teaching their reading classes especially in the situation of global corona pandemic.

\section{REFERENCES}

Afflerbach, P.P.,\& Choa, B. 2011. The classroom assessment of reading. In M.L. Kamil, P.D. Person, E.B.Moje, \& P.P.Afflerbach' (Eds.) Handbook of Reading Research, V, IV. New York: Routledge.

Atkins, J. 2010. “Creating Collaboration”. English Journal, 99(5), 12-13

Chen, C.-H., Chen, S.-H., Hwang, G.-J., \& Yang, T.-C. 2010. "Factors influencing teachers' adoption of a ubiquitous technology application in supporting teacher performance". International Journal of Mobile Learning and Organization, Volume 4, Number 1, 39-54. http://dx.doi.org/10.1504/IJMLO.2010.029953.

Crampton, A., Ragusa, A. T., \& Cavanagh, H. 2012. "Cross discipline investigation of the relationship between academic performance and online resource access by distance education students". Research in Learning Technology. Volume 20, 1-13. http://dx.doi.org/10.3402/rlt.v20i0.14430.

Creswell, J. W. 2008. Educational research: Planning, conducting, and evaluating quantitative and qualitative research (3rd ed.). Upper Saddle River, NJ: Pearson Education, Inc.

Gull, F., \& Shehzad, S. (2015). Effects of Cooperative Learning on Students' Academic Achievement. Journal of Education and Learning (EduLearn), 9(3), 246. https://doi.org/10.11591/edulearn.v9i3.2071.

\section{British, Jurnal Bahasa dan Sastra Inggris}


Gupta, M., \& Ahuja, J. 2014. "Cooperative Integrated Reading Composition (CIRC): Impact on Reading Comprehension Achievement in English Among Seventh Graders". IMPACT: International Journal of Research in Humanities, Arts and Literature (IMPACT: IJRHAL), 2(5), 37-46. Retrieved from http://www.impactjournals.us/journals. php?id=11\&jtype $=2 \&$ page $=8$

Hadiwinarto and Novianti. (2015). The Effects of Using CIRC Model on the English Learning Skills among Junior High School Students. Journal of Education and Learning, 9, 117-124.

Johnson, D., \& Johnson, F. 2009. Joining together: Group theory and group skills (10th ed.). Upper Saddle River, N.J: Pearson Education.

Johnson, D.W., Johnson, R.T. 1999. Learning together and alone: Cooperative, competitive and individualistic learning. USA: Allyn and Bacon.

Johnson, D. W., \& Johnson, R. T. (2017). \& quot; COOPERATIVE LEARNING \&quot; Conference Paper, 11.

Koole, M., Mc.Quilkin, J.L., Ally, M. 2010. "Mobile Learning in Distance Education: Utility or Futility". International Journal of E-Learning \& Distance Education 24 (2).

Mubarok, H., \& Sofiana, N. (2017). Cooperative Integrated Reading and Composition (CIRC) and Reading Motivation: Examining The Effect on Students' Reading Ability. Lingua Cultura, 11(2), 121. https://doi.org/10.21512/lc.v11i2.1824.

Schuler, C., Winters, N., \& West, M. 2012. The future of mobile learning: Implications for policy makers and planners. Paris: UNESCO.

Slavin, R.E.1994. Cooperative learning: Theory, research and practice. 2nd Ed. Boston: Allyn and Bacon.

Sulisworo, D., \& Suryani, F. 2014. "The Effect of Cooperative Learning, Motivation and Information Technology Literacy to Achievement". International Journal of Learning \& Development, Vol. 4, No. 2, 58-64. http://dx.doi.org/10.5296/ijld.v4i2.4908.

Tal, H. M., \& Gross, M. 2014. "Teaching Sustainability via Smartphone Enhanced Experiential Learning in a Botanical Garden”. International Journal of Interactive Mobile Technology, Vol. 8, Issue 1, 10-15. 
Zarei, A. A., \& Keshavarz, J. 2011. "On the Effects of Two Models of Cooperative Learning on EFL Reading Comprehension and Vocabulary". Modern Journal of Language Teaching Methods, 1(2), 38-54. 